\title{
Rapid Approaches for Diagnosis of Canine Distemper Virus in Live and Dead Dogs in Egypt
}

\author{
R. A. Awad \\ Parasitology and Animal Diseases Department, Veterinary Division, National \\ Research Center, Cairo, Egypt.
}

\begin{abstract}
B ACKGROUND: Canine Distemper Virus infection (CDV) is a highly contagious disease of high morbidity and mortality rates in dogs. The causative virus is CDV which is a Morbillivirus, CDV is a pantropic virus characterized by multisystemic infection and high case fatality, with worldwide distribution, so rapid diagnosis and quarantine of the infected dogs with starting suitable treatment was required. The aim: this study aimed to achieve rapid diagnosis of canine distemper virus infection on ante mortem and post mortem aspects. Material and Methods: One healthy control disabled dog, 53 infected dogs with suggestive clinical signs for CDV infection were checked by (a) clinical examination; (b) Rapid immunochromatgrophy (IC) onconjunctival swabs (c) qRT- PCR on blood and tracheal exudates to confirm presence or absence of CDV, by expression analysis of CDV-F gene. Then all 53 examined dogs isolated and received supportive treatment but all died and disabled controlled one exposed to soft death. qRT-PCR were conducted on tissue samples from all 54 dogs for detection CDV-F gene expression values in different tissues.(d) Statistical analysis to study effect of sex and breed using Chi-square test, to evaluate sensitivity, specificity, accuracy, PPV, negative PV, respectively of used test and prevalence of CDV. Results: Clinical signs suggestive for CDV infection recorded in all 53 examined dogs, 24 of 54 dogs were positive for IC. Gene expression analysis test detected high values for CDV- F gene expression in tracheal exudates and blood samples of 36 live dogs, while the expression values were also high in tissue samples from different organs of 36 dead dogs. Statistical comparison of IC to qRT-PCR showed that values were $72 \%, 100 \%$, $81.4 \%, 100 \%$ and 64.2 for sensitivity, specificity, accuracy, PPV, negative PV, respectively. No effect of sex , age, and breed on results using Chi-square test. Prevalence of CDV infection was $66 \%$ among population of this study. Conclusion: this study concluded that detection of clinical signs suggestive for CDV with application of IC and qRT-PCR together should be applied as rapid diagnosis on ante mortem level, while qRT-PCR could be used for rapid post mortem diagnosis of CDV infection.
\end{abstract}

Keywords: Canine Distemper Virus, CDV, qRT-PCR, Immune-chromatography, Dogs, Egypt

\section{Introduction}

Canine Distemper viral (CDV) infection is a highly contagious febrile disease affect dogs. The disease presented as acute and subacute forms manifested clinically by signs of: respiratory manifestations, hyperkeratosis, neurological signs, systemic troubles or combination of them $[1,2]$. The disease characterized by high morbidity and mortality rates $[1,3,4]$.

CD caused by CDV which is a Morbillivirus belongs to Morbillivirus Group, Family
Paramyxovirridae, CDV is a negative single strand RNA. Enveloped, RNA of the virus encoding for 6 structural proteins: Fusion protein (F), Haemagglutinin protein $(\mathrm{H})$, large polymerase $(\mathrm{L})$, nucleoprotein capside $(\mathrm{N})$, protein envelops matrix protein $(\mathrm{M})$ and Phosphoprotein $(\mathrm{P})[4,5]$.

Infection occurs via inhalation, CDV invade upper respiratory tract, lymphoid tissues (6), replicating inside macrophage and monocyte cells [7]. Incubation period varies from one to four weeks depend up on immune-status of dogs and strain virulence $[6,8]$. 
Infected dogs develop a diphasic fever [6,8], in the first viraemic stage generalized infection of all lymphoid tissues characterized by transien fever with lymphoid depletion, lymphopenia, leucocyt ic necrosis and dysfunction end by immune-suppression $[6,9,10]$. In the second viraemic stage secondary viraemia associated with fever and mass infection of all parenchyma tissues, e.g. respiratory tract, GIT, CNS, skin. During the second stage various clinical sign may be founded as nasal discharge, anorexia, conjunctivitis, gastrointestinal tract signs, respiratory signs and neurological disturbance $[6,11,12]$. Interstitial pneumonia and rhinitis is sequel of respiratory tract infection, vomiting, diarrhea and dehydration caused by GIT trac infection, hyperkeratosis of skin.

Neurological signs in the form of hyperesthesia cervical rigidity, seizures, paraparesis, sensory ataxi and cerballer signs which developed as esult of distribution of CDV in CNS tissue [13-15].

Diagnosis of $\mathrm{CDV}$ infection depend mainly up on isolation of the virus in tissue culture (canine cells) but this is a time consuming, taking several days to week [16)]. In spite of vaccination against canine distemper had applied for many decades, CDV infectio still remain fatal disease of dogs [17].

Because of CDV causes a contagious disease of high mortality rates. The need for the use of apid and quarantines of

No published data regarding diagnosis of CDV in Egypt, in addition to importance of establishing definitive diagnostic system for the contro of this disease is urgent. So this study aimed to set a definitive scheme for accurate, rapid diagnosi including clinical signs, the use of immune chromatography (IC) and quantitative Real Time-PCR (qRT-PCR) as rapid test for detection of CDV even in low log of viraemia in live and dead dogs.

\section{Material and Methods}

\section{Duration of the study}

This study has been conducted during the period between January 1, 2015 and Octobe 30, 2018.

Ethical approval and informed consent

We informed and received the permission of the owners of dogs included in this study fo taking samples used in this work. Samples were collected as per standard sample collection procedure without any harm to animals. We received agreement of owner of disabled control puppy for applying soft death, also we received agreement of all dog owners included in this study for using isolated diseased dogs for scarification,taking different tissue samples.

Chemicals

For molecular analysis, Trizol was bough from Invitrogen (Carlsbad, CA, USA). The reverse transcriptase and polymerase chain reactio (PCR) kits were obtained from Fermentas (Gle Burnie, MD, USA). For IC analysis, direct IC k were purchased

(a) 53 diseased dogs were examined. Each dog was examined clinically to detect the clinica manifestations of the disease. (b) One congenitally disabled healthy German Shepherd puppy of 90 day age old suffered from congenital disability in his hind limb and according to private personal request of the owner to make soft death of his disabled puppy $[19,20]$.

Clinical examination

Fifty three infected dogs and a healthy contro disabled puppy were received at a Clinic at 6 October district located in Giza Governorate, Egypt. History of the examined dogs including breed, sex, age, past medical data history, an registered vaccination were recorded. Dogs subjected to general and specific clinica severity of the clining signs observed in this study severity of he clinical signs observed in this study was recorded as seve

Sampling

Conjunctival swabs were collected from all clinically infected cases dogs and a healthy control disabled puppy was checked by rapid IC tes (rapid CDV Ag test kit for qualitative detection of viral antigen in samples of all examined cases). For detection of CDV-F gene expression values on tracheal exudates and blood of all live dogs.

After death, liver, spleen, myocardium, lung, brain tissues and lymph nodes (mediastinal an retropharyngeal) were collected from all infected dogs and a healthy control disabled puppy after nine distemper virus infection. Collocted of cawere stored in $2 \mathrm{ml}$ micho of $-80^{\circ} \mathrm{C}$.
Immune-chromatography (IC)

Direct IC (the antigen rapid CDV Ag test kit, Bionote Inc., Korea) for the qualitative detection of Canine Distemper antigen in Canine conjunctival swabs were carried out on 53 infected dogs and a healthy control disabled puppy samples showing clinical signs of CDV viral infection [21].

Molecular study

Extraction of total RNA and cDNA synthesis Tracheal exudates and blood from live dog (n=54), in addition to liver, spleen, myocardium, lang, brain tissues and lymph nodes (mediastinar (n) collo

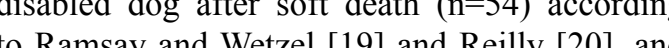

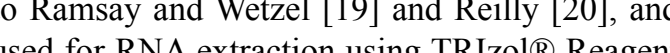
(Invitrogen, German) Kit. The isol Reagent

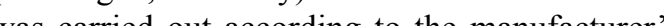
instructions of the above Kit. Approximately 50 mof the samps were homogenized in 1 ml of TRIzol R Reagent in Eppendorf tubes. Afterwards total RNA was dissolved and preserved diethylpyrocabon (DEPC)-treated water up to use [22, 23].

To assess the RNA yield and purity of the total RNA, RNAse-free DNAse I (hnvitrogen, Germany) was used to digest DNA contamination A small drop of isolated RNA was examined photospectrometrically at $260 \mathrm{~nm}$. The purity of total RNA was determined between 1.8 an $2.1 \mathrm{mg}$ to be good purified when it examined by spectrophotometer at the 260/280 nm ratio. To avoid RNA damaging, aliquots of RNA were prepared after isolation for either reverse ranscription reaction or otherwise for storing at $-80^{\circ} \mathrm{C}$ up to use.

To synthesize the complementary DNA (cDNA) isolated RNA from all samples were reverse transcribed into cDNA. The reaction volume was carried out in $20 \mu$ l. The reaction volume was prepared according to the instructions of the RevertAidTM First Strand cDNA Synthesis Kit (MBI Fermentas, Germany). The reverse transcription (RT) reaction was performed for 10 min at $25^{\circ} \mathrm{C}$. Afterwards, the tubes of the reactio were put in thermo-cycler machine for $60 \mathrm{~min}$ $42^{\circ} \mathrm{C}$, and then the reaction was terminated for 5 min at $99^{\circ} \mathrm{C}$. The PCR products containing the cDNA were kept at $-80^{\circ} \mathrm{C}$ up to use for DNA amplification $[22,23]$.

Quantitative Real Time-PCR (qRT-PCR)

Specific primers used in this study were esigned for different regions in as illustrated in Table 1.

A StepOne Real-Time PCR System (Applied Biosystem, USA) was used to assess the copy of the cDNA of tracheal exudates, liver, spleen, myocardium, lung, brain tissues and lymph nodes (mediastinal and retropharyngeal) to detect the expression values of the Canine Distemper virus F-gene. A volume of $25 \mu \mathrm{L}$ of reaction mixtures was prepared containing $12.5 \mu \mathrm{l}$ of SYBR $^{\circledR}$ green (TaKaRa, Biotech. Co. Ltd.), $0.5 \mu 1$ of forward and reverse primers, $6.5 \mu \mathrm{LDNA}$-RNA free water, and $2.5 \mu$ of the synthesized cDNA. A melting curve of the reaction was performed for each qRT-PCR termination at $95.0^{\circ} \mathrm{C}$ to assess the quality of the primers. To verify that the reaction of the qRT-PCR does not have any contamination PCR tubes containing non template control were used. The sequences of specific primers of the Canine Distemper virus F-gene were used Table 1. The relative quantification of the target gene to the reference (GAPDH, [24] was determined by using the $2-\Delta \Delta C T$ method $[22,23]$.

\begin{tabular}{|c|c|c|c|c|c|}
\hline No & Gene & $\begin{array}{c}\text { Primer } \\
\text { Name }\end{array}$ & $\begin{array}{l}\text { Oligonucleotide sequence } \\
\qquad(' 3-5)\end{array}$ & $\begin{array}{c}\text { Estimated } \\
\text { (size } \mathrm{e}^{\mathrm{a}(\mathrm{bp}} \text { product }\end{array}$ & $\begin{array}{c}\text { Reference/ } \\
\text { Accession } \\
\text { number }\end{array}$ \\
\hline \multirow{2}{*}{1} & \multirow{2}{*}{ CDV-F } & $\mathrm{F}$ & CGTCGCAAATTGTGCTTCTA & \multirow{2}{*}{$1579-1821$} & \multirow{2}{*}{ M21849.1 } \\
\hline & & $\mathrm{R}$ & AGGGCGTTCCCTAAGTTTGT & & \\
\hline \multirow{2}{*}{2} & GAPDH & $\mathrm{F}$ & GAGAAAGCTGCCAAATATG & \multirow{2}{*}{193} & \multirow{2}{*}{ Tarlinton [24 } \\
\hline & & $\mathrm{R}$ & CCAGGAAATGACCTTGACA & & \\
\hline
\end{tabular}

äased on available $\mathrm{CDV}$ genome sequences. $\mathrm{CDV}=$ Canine Distemper vir 
Statistical Analysis

The statistical analysis of the obtained results was done using Chi-square test to study the effect of age, sex and breeds on results of different tests. Sensitivity, specificity, accuracy, $\mathrm{P}$ ositive predictive value (PPV) and negative predictive values (NPV) of used diagnostic tes and prevalence of the disease in population of this study were calculated according to Smith [25].

\section{Results}

Clinical examination

The severity of the disease varied from sever acute to subacute moderate form or latent mild

form that was fatal usually in puppies.

Fifty three naturally infected puppies, 1 disabled healthy control male German Shepher of age 2 to 4 months of history with vaccination against Distemper virus were kept under close observation and taking all sanitary and epidemiological measures for prevention

The observed clinical signs were:

-Non neurological signs: fever $40-41.7^{\circ} \mathrm{C}$ serous - mucopuralant nasal and conjunctiva discharge, coughing, dyspnea, vomiting and diarrhea as shown in Table 2 and Fig. 1.

TABLE 2. The clinical signs detected in examined dogs.

\begin{tabular}{|c|c|c|c|c|c|c|c|c|c|}
\hline \multirow{2}{*}{ Breed } & \multirow{2}{*}{$\begin{array}{c}\text { No. } \\
\text { of } \\
\text { cases }\end{array}$} & \multicolumn{2}{|c|}{ Breed size } & \multirow{2}{*}{$\begin{array}{c}\text { Age } \\
(\text { mon })\end{array}$} & \multicolumn{2}{|c|}{ Sex } & \multirow{2}{*}{$\begin{array}{l}\text { Fever } \\
\left({ }^{\circ} \mathrm{C}\right)\end{array}$} & \multicolumn{2}{|c|}{ Clinical Signs } \\
\hline & & Small & Large & & Male & Female & & $\begin{array}{c}\text { Non } \\
\text { neurological* }\end{array}$ & Neurological $^{* *}$ \\
\hline German Shepherd & 16 & - & 16 & $2-3$ & 9 & 7 & $40-41.6$ & Severe & Moderate \\
\hline Golden Retriever & 15 & - & 15 & $2-3$ & 7 & 8 & $40-41.5$ & Seve & Severe \\
\hline Yorkshire & 3 & 3 & - & $2-3$ & 2 & 1 & $40-41$ & Moderate & Severe \\
\hline Labrador Retriever & 12 & - & 12 & $2-3$ & 6 & 6 & $40-41.3$ & Severe & Moderate \\
\hline Griffon & 5 & 5 & - & $2-3$ & 2 & 3 & $40-41.5$ & Severe & Severe \\
\hline Boxer & 3 & - & 3 & $3-4$ & 2 & 1 & $40-41.7$ & Mild & Moderate \\
\hline Total & 54 & 8 & 46 & & 28 & 26 & & & \\
\hline
\end{tabular}

* Fever $40-41.7{ }^{\circ} \mathrm{C}$ serous - mucopuralant nasal and conjunctival discharge, coughing, dyspnea, vomiting and diarrhea ** Shewing gums, seizures, circling, continues fits of high voices, later end by limb ataxia and weakness, head tremors, head tilt, depression. The severity of clinical signs evaluated as mild, moderate and severe.

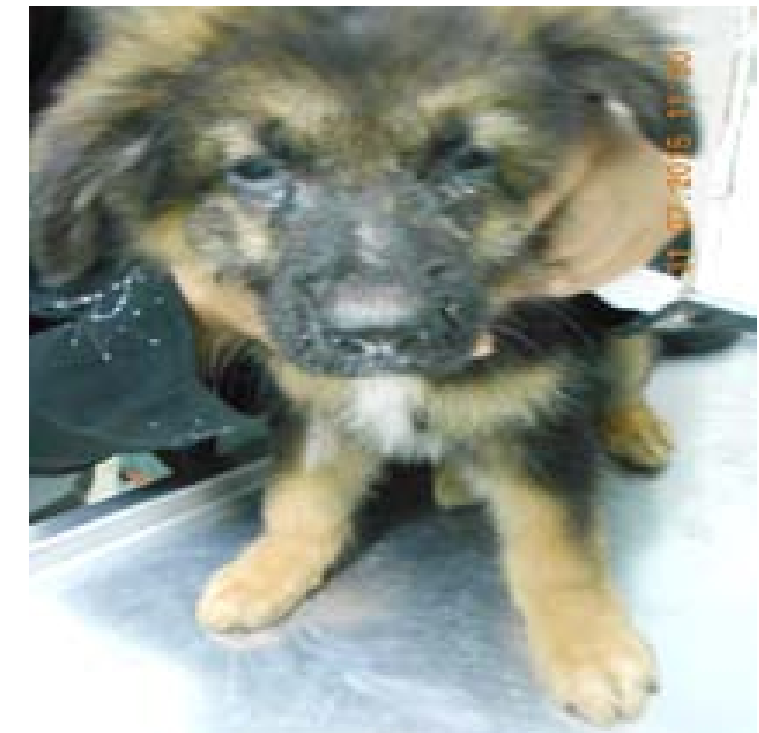

Fig. 1: German Shepherd puppy infected with CDV with chronic respiratory form (non-neurological form) Egypt. J. Vet. Sci. Vol. 50, No.1 (2019)

- Neurological signs: includes shewing gums, seizures, circling, continues fits of high voices, later end by limb ataxia and weakness, head tremors, head tilt, depression, behavior changes end by death as shown in Table 2 .

Immune-chromatography (IC)

All hospitalized infected puppies that showe clinical signs were checked by rapid Immune-

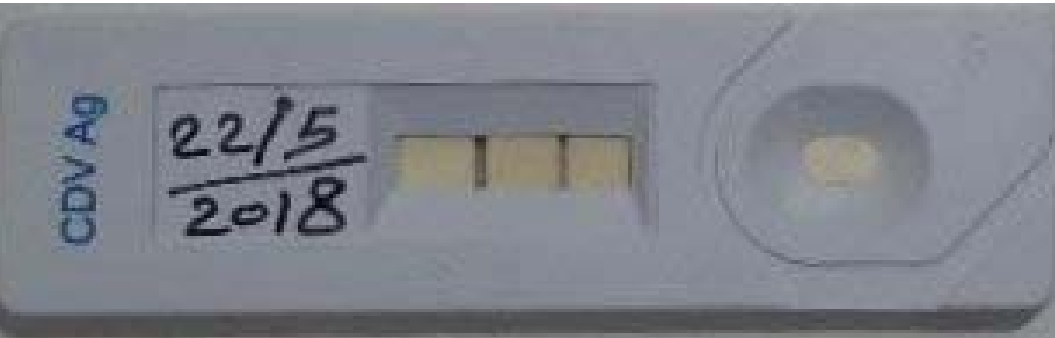

Fig. 2. Immune chromatography test kit showing positive results for $\mathrm{CDV}$ infection

TABLE 3. Positive and negative male and females dogs examined for CDV using Immune-chromatography.

\begin{tabular}{lcc}
\hline \multirow{2}{*}{ Case } & \multicolumn{2}{c}{ Percentage (\%) } \\
\cline { 2 - 3 } & Male & Female \\
\hline Positive & $14(50)$ & $12(46)$ \\
Negative & $14(50)$ & $14(54)$ \\
Total & $(100) 28$ & $26(100)$ \\
\hline
\end{tabular}

Figure 3 represents the levels of Distemper virus F-gene expression in different Tracheal exudates and blood samples of live dogs (Fig. 3). The CVD-F gene expression values were highe significantly in tracheal exudates than in bloo undetectable in control dog samples.

Figure 4 represents the levels of Distemper viru -gene expression in liver, spleen, myocardium, lung, brain and retropharngial \& mediastinal lymph nodes samples of infected dogs.

The results revealed that the Distemper viru F-gene was of low values and undetectable in al control dog tissues. However, expression values of Distemper virus F-gene in different infected dog issues were significantly higher when compared with the control dog tissue samples. In addition to the expression values of Distemper virus F-gene increased significantly with differ lung tissues\&lymph with liver, myocardium and spleen (Fig. 4). chromatography (IC) for qualitative detection of canine distemper viral antigen in conjunctival discharge, the 26 mentioned puppies were positive when checked by rapid IC test as mentioned in Fig. 2 and Tabe
were negative.

Molecular stud

Expression levels of CDV-F gene in dog tissues

Statistical analysis

Results of statistical analysis proved that sex, age and breed have no significant effect on results of both IC and qRT-PCR. qRT-PCR is considere as gold standard of this study. Table (4) represents the comparison between IC and qRT-PCR showing $72 \%, 100 \%, 81.4 .65 \%, 100 \%$ and $64.2 \%$ on sensitivity, specificity, accuracy, positive predictive value and negative protective value. Prevalence of CDV infection among populatio of this study was $66 \%$

Discussion

Clinical examination considered as the firs utility for diagnosing of CDV infection in this study, it detected clinical signs in the form of non neurological and neurological signs which were suggestive for CDV infection as stated by Gaskell et al.[1].But these recorded clinic signs clinically confused with other neurologica and non neurological respiratory diseases confirmed by Shaw and Ihle [26]

So, IC applied as a rapid field test reliable for diagnosis of CDV infection in veterinary clinic Egypt. J. Vet. Sci. Vol. 50, No.1 (2019) 


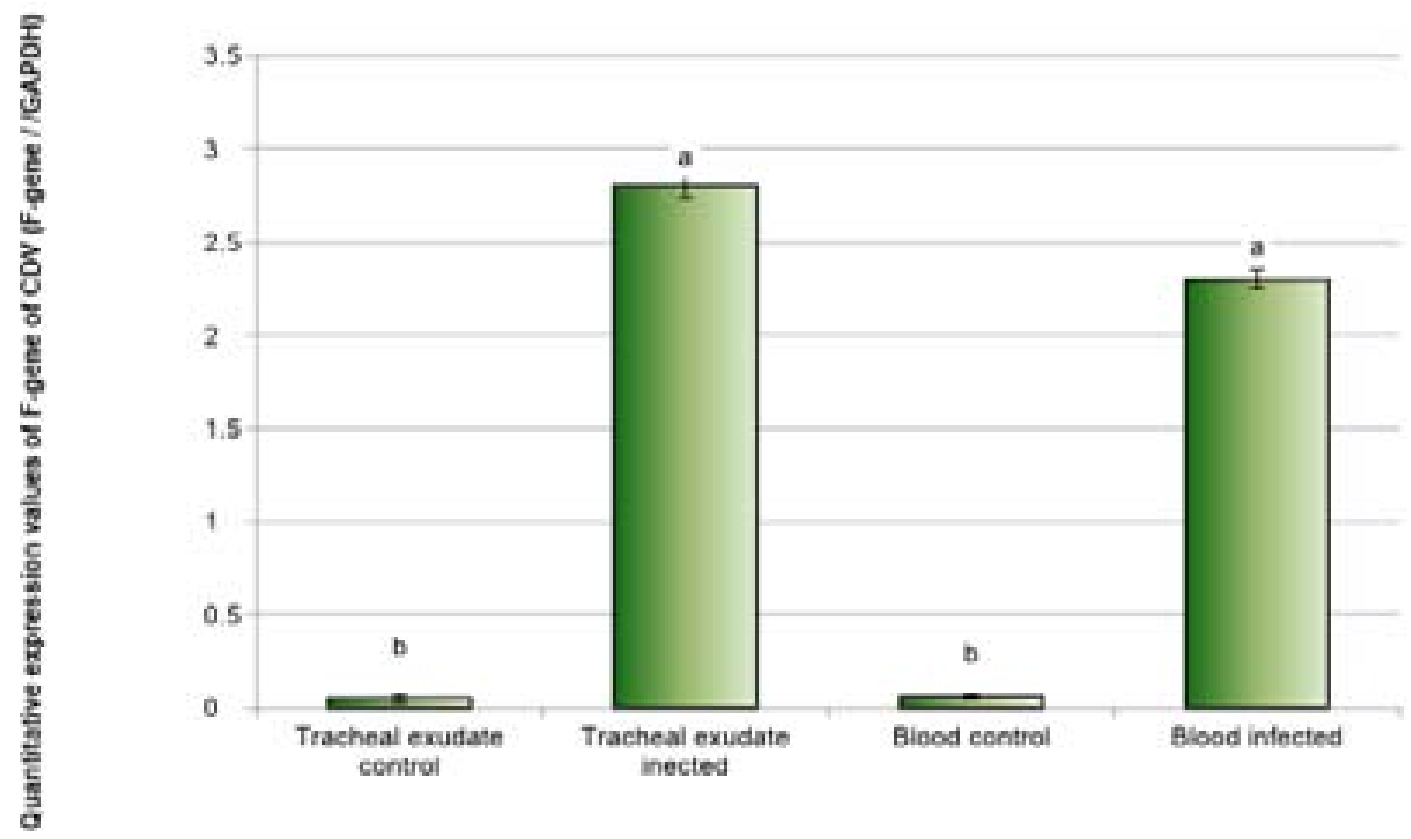

Examined samples of live dogs

Fig. 3. Expression levels of F-gene of CDV in diterent tive dog samples. Data are presented as mean $\pm \mathrm{SEM}$. a, followed by different superscripts are significantly different $(\mathbf{P} \leq \mathbf{0 . 0 5})$.

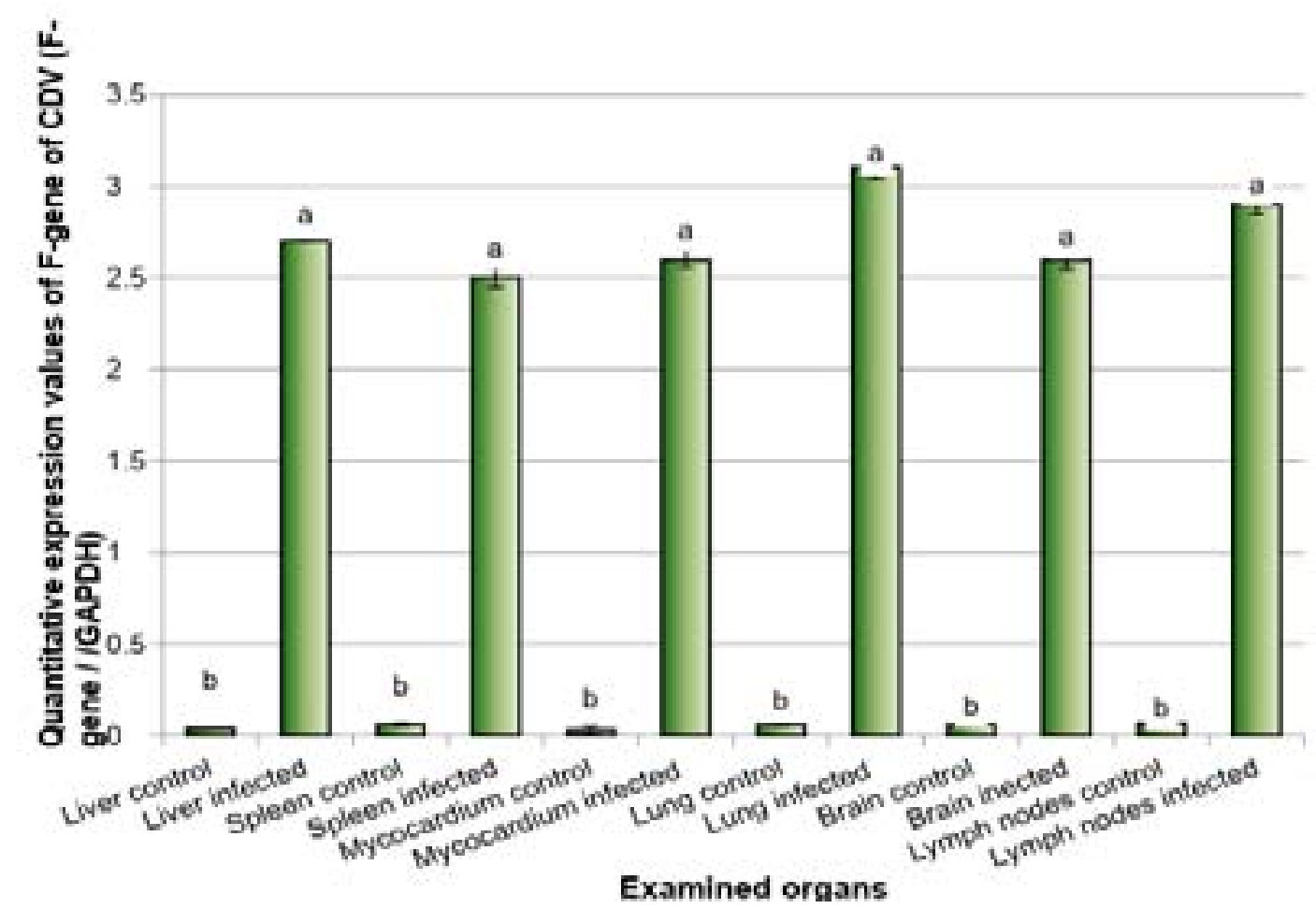

Fig. 4. Expression levels of $\mathrm{F}$-gene of $\mathrm{CDV}$ in different dead dog samples. Data are presented as mean $\pm \mathrm{SEM}$. a, followed by different superscripts are significantly different $(\mathbf{P} \leq 0.05)$

Egypt. J. Vet. Sci. Vol. 50, No.1 (2019)

TABLE 4. Comparison between immune-chromatography (IC) according qRT-PCR findings of examined cases of CDV in live dogs.

\begin{tabular}{ccccc}
\hline \multirow{2}{*}{ Method of identification } & & \multicolumn{2}{c}{ IC } & \multirow{2}{*}{ Total } \\
\cline { 3 - 4 } & & Positive & Negative & \\
\hline \multirow{2}{*}{ qRT-PCR } & Positive & $26(\mathrm{~T}+)$ & $10(\mathrm{~F}-)$ & 36 \\
& negative & $0(\mathrm{~F}+)$ & $18(\mathrm{~T}-)$ & 18 \\
\hline & Total & 26 & 28 & 54 \\
\hline
\end{tabular}

$(\mathrm{T}+)$ : True positive, (T-): True negative, $(\mathrm{F}+)$ : False positive, $(\mathrm{F}-)$ : False negative $\begin{array}{ll}\text { Sensitivity }=72 \% & \text { Positive pre-detective values }(+\mathrm{PPV})=100 \% \\ \text { Specificity }=100 \% & \text { Negative pre-detective values }(\mathrm{NPV}=64.2 \%\end{array}$

Specificity $=100 \%$

\& hospitals. It proved to be specific, easily in performance for detection of CDV antigen in conjunctival swabs of examined dogs as reported by An et al. [21].

IC succeeded in detection of 26 infected cases among 54 examined dogs, due to lack in its sensitivity for detection the infected cases harboring low concentration 105.5 $\mathrm{TCID}_{50} / \mathrm{ml}[27]$.

In this work Gene expression analysis test (qRT-PCR) tried as highly sensitive, specific test with high accuracy in detection of CDV-F gene expression using specific primer on blood gnd expel exudate of examined on blood recon recommended by. Elia

qRT-PCR in this study succeeded in detection of 36 infected cases among 54 suspected cases due to its high sensitivity in detection of CDV-F gen to ispresion even in very low vius conc $F$ gene which may rech to $10^{2}$ as con col by al. [18].

These results proved that gene expression analysis test was an accurate, conclusive, confirmatory, qualitative test in diagnosis of CDV infection in live dogs as confirmed by many authors [Elia et al. [18] and Shaw \& Ihle [26]. Moreover that qRT-PCR was a sensitive ant mortem diagnostic technique especially reliable mortem diagnostic technique especially reliable
in sub acute and chronic stages of CDV infection in sub acute and

Results of qRT-PCR when applied in liver, spleen, myocardium, lung, retropharngeal \& mediastinal lymph nodes and brain tissue of dead dogs, showed that CDV-F gene expression values were high in lung \& lymph nodes than that values of liver, spleen, myocardium and brain significantly $(\mathrm{P}<0.05)$, while there is no significant difference between expression values of liver, spleen, myocardium, and brain tissues agreed with Elia et al. [18]

The above mentioned results recommend the use of qRT-PCR as quantitative assay for measuring CDV load \& distribution in different infected organs by estimating CDV-F gene expression quantitatively, with high accuracy because it can detect CDV even in level $10^{2}$ to $10^{8}$ So, qRT-PCR served as reproducible assay for studying pathogenetic mechanisms induced by CDV [17, 18, 30]. Moreover, the gene expression values in blood and tracheal exudate were high as that recorded in lung tissue, these findings nominate qRT-PCR as rapid molecular assay for studying CDV spread and shedding [18, 28, 30-35].

\section{Conclusion}

This study concluded that detection of clinical signs suggestive for $\mathrm{CDV}$, application of rapid IC and molecular assaying by qRT-PCR could serve as rapid, accurate, confirmatory methods of CDV diagnosis on ante-mortem level without need fo CDV isolation, while GRT-PCR was considered as accurate assay for rapid diagnosis on post-morte level.

\section{Acknowledgments}

The author is grateful to Dr. Brit Martens and Prof. Safwat Ali Hassan, Small Animals Referral Hospital- Merkurring 50, 22143 Hamburg-Rahlstedt, Germany, for the scientific support regarding the epidemiological data about the CDV infection in Germany. Also, the author is grateful 
for Prof. Dr. Sobhy Abd-Elshafy, Parasitology and Animal Diseases Department, Veterinary Division, National Research Center, Giza, Egypt, for providing the technical and scientific consultant regarding statistical analysis of data. The author also is grateful for Prof. Dr. Wagdy K. B. Khall for his great help in achieving moloch B. Khali finalizing of this mats The present study received no financial support.

Conflict of Interest Statemen

The author whose name is listed immediately below certify that he has no affiliations with or involvement in any organization or entity with any financial interest (such as honoraria; educational grants; participation in speakers' bureaus; membership, employment, consultancies, stock ownership, or other equity interest; and expert testimony or patent-licensing arrangempents), or nonfinacial interest (such as personal or professional relationships, affilitions, knowledge or beliefs) in the subject matter or mote discussed in this manuscript.

Author contribution

The author performed the study plan and design. Romane Adieb Awad collected the samples from the clinic, and had carried out the clinical examination and IC laboratory work. Romane Adieb Awad carried out the work of clinical evaluatio of the diseased dogs, treatment, clinical follow-up and assessment. He also has carried out the molecular work included in this study Rom the moAwad had done all issues of witing revising, and A

\section{Ethical consideration}

The owners of dogs were informed and permission was received from them. The dog included in this study for taking samples used in this work. Samples were collected as per standard sample collection procedure without any harm to animals. Individual permission received from the owner of the disabled control puppy and up on his request to do soft death of his disabled control puppy. The propose of this study had approval from Nation Research Center committee no: 10/01/2015.

\section{Reference}

1. Gaskell, R.M., Tennant, B., Bennett, M. and Willoughby, K. Feline and Canine Infectious Diseases. Published by Iowa State Press, Ames, IA 1996.

2. Appel, M.J.G. and Summers, B.A., Pathogenicity of morbilliviruses for terrestrial carnivores. Vet. Microbiol., 44, 187-191 (1995).

3. FroÈlicha, K., Czupalla, O., Haas, L., Hentschke, J., Dedek, J. and Fickel, J.E., Epizootiologica investigations of canine distemper virus in free-

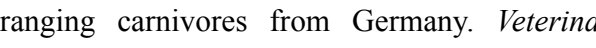
Microbiology, 74, 283 - 292 (2000).

4. Greene, C.E. and Appel, M.J.G., Canine distemper: In: Greene, C.E. (Ed.) Infections Diseases of the dog and cat. W.B. Saunders, Philadelphia, pp. 2541. (2006).

5. Pardo, I.D.R., Johnson, G.C. and Kleiboeker, S.B., Phylogenetic Characterization of Canine Distemper Viruses Detected in Naturally Infected Dogs in North America. Journal of Clinical Microbiology, 5009-5017 (2005).

6. Krakowka, S., Higgins, R.J. and Koestner, A Canine distemper virus: review of structural an tissues, $A m$ J. Vet. Res., 41, 284-292 (1980).

7. Appel, MJG, Pathogenesis of canine distemper Am. J. Vet. Res., 30, 1167-1182 (1969).

8. Wright, N.G., Cornwell, H.J., Thompson, H. and Lauder, I.M., Canine distemper. current concepts in laboratory and clinical diagnosis. Vet. Rec., 94, 86-92 (1974).

9. Schobesberger, M., Summerfield, A., Doherr, M.G., Zurbriggen, A. and Griot, C., Canin distemper virus-induced depletion of uninfected lymphocytes is associated with apoptosis, Immunol. Immunopathol. 104, 33-44 (2005).

10. Qeska, V., Barthel, Y., Herder, V., Stein, V.M., Tipold, A., Urhausen, C., Günzel-Apel, A.R. Rohn, K., Baumgärtner, W., Beineke, A., Canine distemper virus infection leads to an inhibitory phenotype ofmonocyte-derived dendritic cells in vitrowith reduced expression of co-stimulatory molecules and increased interleukin-10 transcription. PLoS One 9, e96121 (2014).

11. Appel, M.J., Distemper pathogenesis in dogs. $J$ Am. Vet. Med. Assoc., 156, 1681-1684 (1997).

12. Decaro, N., Camero, M., Greco, G., Zizzo, N., Tinelli, A., Campolo, M., Pratelli, A. and diseases. Report of a ser- on New Microbiol, 27, 177-181 (2004).
13. Deem, S.L., Spelman, L.H., Yates, R.A. and Montali, R.J., Canine distemper in terrestria carnivores: a review, J. Zoo Wildl. Med., 31, 441451 (2000).

14. Baumgärtner, W., Boyce, R.W., Alldinger, S Axthelm, M.K., Weisbrode, S.E., Krakowka, S. and Gaedke, K., Metaphyseal bone lesions in young dogs with systenic canine distemper viris infection. Vet. Microbiol., 44, 201-209 (1995).

15. Von Rüden, E.L., Avemary, J., Zellinger, C., Algermissen, D., Bock, P., Beineke, A. Baumgärtner, W., Stein, V.M., Tipold, A. an Potschka, H., Distemper virus encephalitis exert detrimental effects on hippocampal neurogenesis, Neuropathol. Appl. Neurobiol., 38, 426-442 (2012).

16. Kim, Y.H., Cho, K.W., Youn, H.Y., Yoo, H.S. and Han H.R., Detection of canine distemper virus (CDV) through one step RT-PCR combined wit nested PCR. J. Vet. Sci, 2, 59-63 (2001).

17. Jóźwik, A. and Fryms, T., Comparison of the immunofluorescence assay with RT-PCR and neste PCR in the diagnosis of Canine Distemper. Veterinary Research Communications, 29, 347-359

18. Elia, G., Decaro, N., Martella, V., Cirone, F., Lucente, M.S, Lorusso, E, Trani, L. D. and Buoravoglia, C., Detection of canine distemper virus in dogs by real-time $\mathrm{PCR}$. Journal of Virological Methods, 136, 171-176 (2006)

19. Ramsay, E.C. and Wetzel, R.W., Comparison of five regimens for oral administration of medication to induce sedation in dogs prior to euthanasia. J Am Vet Med Assoc, 213 (2), 240-242 (1998).

20. Reilly, J.S., Euthanasia of animals used for scientific purposes. Australian and New Zealand Council for the Care of Animals in Research and Teaching. Adelaide, Australi, (1993).

21. An, D.J., Kim, T.Y., Song, D.S., Kang, B.K., Park, B.K. An immunochromatography assay for rapid antemortem diagnosis of dog suspected to have canine distemper, $J$ Vivol. Methods, 147 (2), 244 249 (2008).

22. Awad, R.A., Khalil, W.K.B. and Attallah, A.G

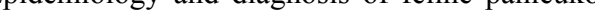
penia virus in Egypt. Clinical and molecular diagnosis in cats. Veterinary World, 11 (5), 578-584 (2018)
23. Awad, R.A., Khalil, W.K.B. and Attallah, A.G Feline panleukopenia viral infection in cats: Application of some molecular methods used for its diagnosis. Journal of Genetic Engineering and Biotechnology, 16, 491-497 (2018).

24. Tarlinton, R.E., Barfoot H.K., Allen C.E., Brow K., Gifford R.J. and Emes R.D., Characterisatio of a group of endogenous gammaretroviruses the canine genomo. Wethinary Journal, 196, 2833 (2013).

25. Smith, R.D., Veterinary Clinical Epidemiology 3rd ed. CRC Press, Boca Raton., (2005).

26. Shaw, D.H. and Ihle S.L., Small animal interna medicine, published by Williams and Wilkins, chapter 47, p 464-468 (1997).

27. Soma, T., Soma, T., Ishii, H., Hara, M., Ohe $\mathrm{K}$, Hagimori, I, Ishikawa, Y, Taneno, A. Detection C Canine Distenper virus antigen in Canine serum 499-501 (2003).

28. Budaszewski, R.D.F. and Von Messling, V. Morbillivirus Experimental Animal Models: Measles Virus Pathogenesis Insights from Canine Distemper Virus. Viruses., 8 (10), 274 (2016).

29. Wang, J., Wang, J., Li, R., Shi, R., Liu, L. and Yuan, W. Evaluation of an incubation instrumentfree reverse transcription recombinase polymerase amplification assay for rapid and point-of-need detection of canine distemper virus. J. Virol. Methods., 260, 56-61 (2018).

30. Wang, J., Wang, J., Li, R., Liu, L. and Yuan, W. Rapid and sensitive detection of canin distemper virus by real-time reverse transcription recombinase polymerase amplification. $B M C$ Vet Res., 13 (1), 241 (2017).

31. Nemeth, N.M., Oesterle, P.T., Campbell, G.D. Ojkic, D. and Jardine, C.M., Comparison
of reverse-transcription real-time PCR and immunohistochemistry for the detection of canin distemper virus infection in raccoons in Ontario, Canada. J. Vet. Diagn. Invest. 30 (2), 319-323 (2018).

32. Sehata, G., Sato, H., Ito, H., Imaizumi, Y., Noro, T. and OISHI E., Use of quantitative real-time RT-PCR to investigate the correlation between viremia and viral shedding of canine distemper virus, and infection outcomes in experimentally infected dogs. J. Vet. Med. Sci, 77 (7), 851-855 (2015).

Egypt. J. Vet. Sci. Vol. 50, №.1 (2019) 
33. Willi, B., Spiri, A.M., Meli, M.L., Grimm, F., Beatrice, L., Riond, B., Bley, T., Jordi, R., Dennler, M. and Hofmann-Lehmann, R., Clinical and molecular investigation of a canine distemper outbreak and vector-borne infections in a group of rescue dogs imported from Hungary to Switzerland. BMC Vet. Res., 11, 154 (2015).

34. Riley, M.C. and Wilkes, R.P., Sequencing of emerging canine distemper virus strain reveals new distinct genetic lineage in the United States associated with disease in wildlife and domestic canine populations. Virol. J., 12, 219 (2015).
35. Wang, J., Li, R., Shi, R., Liu, L. and Yuan, W., Evaluation of an incubation instrument-free reverse transcription recombinase polymerase amplification assay for rapid and point-of-need detection of canine distemper virus. J. Virol. Methods., 260, 56-61 (2018).

(Received 04/04/2019; accepted 14/04/2019)

\title{
تقنيات سريعة لتشخيص فيروس الاستمبر فى الكلاب الحية والميتة فى مصر

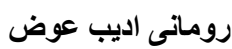 \\ قسم الطفيليات وامر اض الحيو انـ شعبة البحوث البيطريةـ المركز القومى للبحوث ـ القاهرة ـ مصر.
}

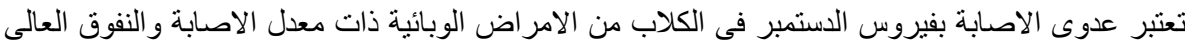

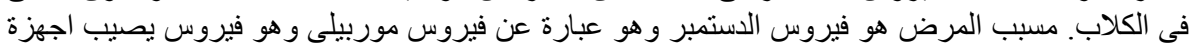

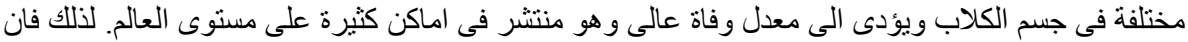

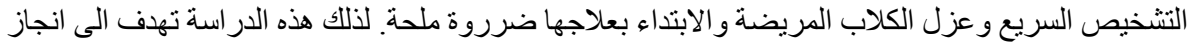

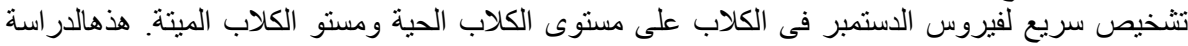

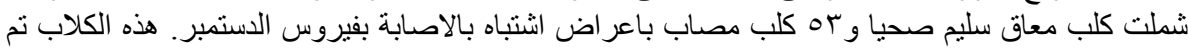

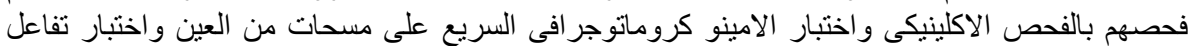

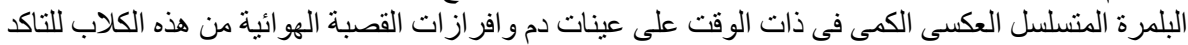

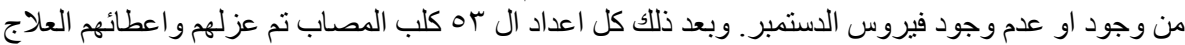

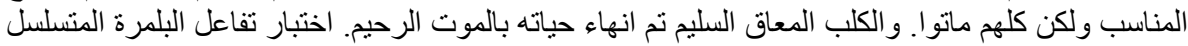

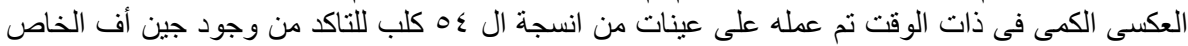

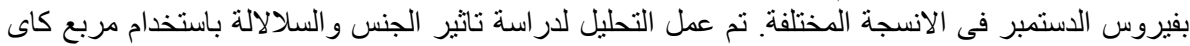

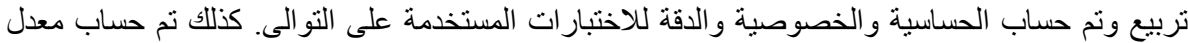

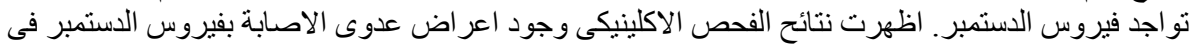

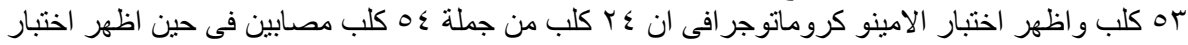

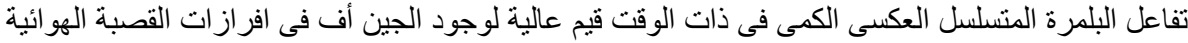

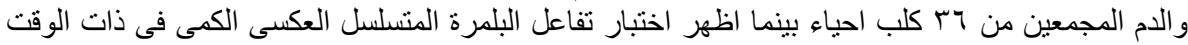

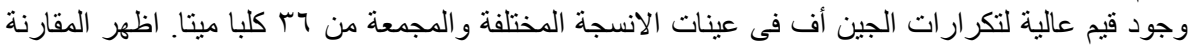

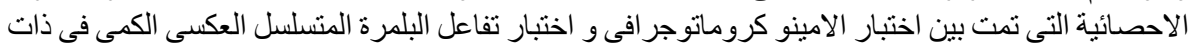

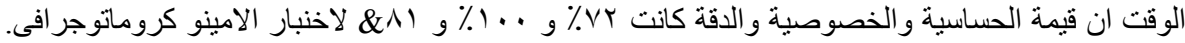

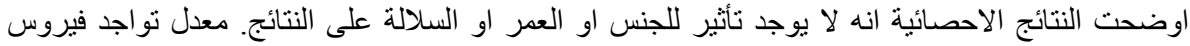

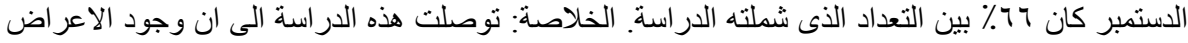

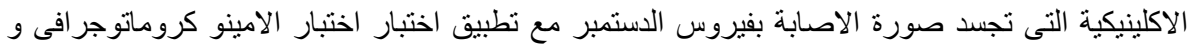

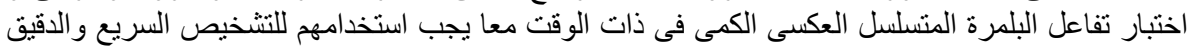

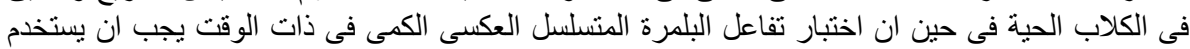
للتشخيص السريع لعدوى فيروس الدستمبر فئ فئ الكلاب الميتة.
\end{abstract}

